\title{
Inhibitory Effects of Blue Light-Emitting Diode Irradiation on Podosphaera xanthii Conidial Release and Infection of Melon Seedlings
}

\author{
Tomoko Suzuki ${ }^{1,2}$, Shota Iwasaki ${ }^{3}$, Hatsune Hisazumi ${ }^{3}$, Ayumi Miyamoto ${ }^{3}$, Hayato Ogami ${ }^{3}$, \\ Yoshihiro Takikawa ${ }^{4}$, Koji Kakutani ${ }^{5}$, Yoshinori Matsuda ${ }^{3}$ (D) and Teruo Nonomura ${ }^{3,6, *(D)}$
}

\section{Citation: Suzuki, T.; Iwasaki, S.;}

Hisazumi, H.; Miyamoto, A.;

Ogami, H.; Takikawa, Y.;

Kakutani, K.; Matsuda, Y.;

Nonomura, T. Inhibitory Effects of Blue Light-Emitting Diode Irradiation on Podosphaera xanthii Conidial Release and Infection of Melon Seedlings. Agriculture 2022, 12, 198. https://doi.org/10.3390/ agriculture12020198

Academic Editor: Éva Darkó

Received: 23 December 2021

Accepted: 29 January 2022

Published: 31 January 2022

Publisher's Note: MDPI stays neutral with regard to jurisdictional claims in published maps and institutional affiliations.

Copyright: (C) 2022 by the authors. Licensee MDPI, Basel, Switzerland. This article is an open access article distributed under the terms and conditions of the Creative Commons Attribution (CC BY) license (https:// creativecommons.org/licenses/by/ $4.0 /)$.
1 Department of Chemical and Biological Sciences, Faculty of Science, Japan Women's University, Tokyo 112-8681, Japan; suzukit@fc.jwu.ac.jp

2 Mass Spectrometry and Microscopy Unit, Technology Platform Division, RIKEN Center for Sustainable Resource Science, Kanagawa 230-0045, Japan

3 Department of Agricultural Science, Faculty of Agriculture, Kindai University, Nara 631-8505, Japan; 2033650007j@nara.kindai.ac.jp (S.I.); 1811410120y@nara.kindai.ac.jp (H.H.); 1811410154s@nara.kindai.ac.jp (A.M.); 1811410169y@nara.kindai.ac.jp (H.O.); ymatsuda@nara.kindai.ac.jp (Y.M.)

4 Plant Center, Institute of Advanced Technology, Kindai University, Wakayama 642-0017, Japan; takikawa@waka.kindai.ac.jp

5 Pharmaceutical Research and Technology Institute and Anti-Aging Centers, Kindai University, Osaka 577-8502, Japan; kakutani@kindai.ac.jp

6 Agricultural Technology and Innovation Research Institute, Kindai University, Nara 631-8505, Japan

* Correspondence: nonomura@nara.kindai.ac.jp; Tel.: +81-742-43-5194

\begin{abstract}
Powdery mildew fungi infect plant leaves, reducing the yield of infected melon plants. Therefore, an eco-friendly method of controlling powdery mildew in melon plants needs to be developed. A previous study described how the morphological characteristics of the conidiophores of the melon powdery mildew fungus Podosphaera xanthii Pollacci (designated KMP-6N) grown under greenhouse (natural) conditions and red light-emitting diode (LED) irradiation differed from those grown under growth chamber conditions and blue LED irradiation. In the present study, conidiophores with unconstricted conidia under blue light were collected and inoculated onto host leaves through micromanipulation; the unconstricted conidia germinated and infected the leaves, producing vigorously elongated hyphae. The number of conidia collected, the initial times of conidial release from single colonies, and the number of conidia remaining in chains on conidiophores were examined with electrostatic techniques. Under red light, the number of collected conidia gradually increased with the light irradiation period. The initial conidial release occurred between 2 to $4 \mathrm{~h}$; the number of conidia remaining on the conidiophores gradually decreased and, eventually, the conidiophore lengths became shorter. In contrast, under blue light, few conidia were collected at any given time; the number of conidia on the conidiophores gradually increased and, eventually, the conidiophore lengths became longer. Next, the effects of red and blue light on the spread of powdery mildew infection by placing a KMP-6N-infected melon seedling at the centre of a tray containing healthy melon seedlings were examined. Almost all healthy seedlings caused powdery mildew symptoms at ca. 21 days after red light irradiation, whereas only healthy seedlings near the infected seedlings showed symptoms after blue light irradiation. Thus, the spread of melon powdery mildew infection clearly differed between red and blue light irradiation. This is the first report describing the effects of red and blue light on the spread of $P$. xanthii infection from a single infected seedling to healthy host seedlings; their results provide insight into the ecological mechanisms of powdery mildew conidial scatter from conidiophores.
\end{abstract}

Keywords: Cucumis melo; conidiophore formation; electrostatic spore collector; LED light; melon powdery mildew 


\section{Introduction}

The powdery mildew infection of melon species can be caused by multiple fungi, including polygoni-type Oidium sp. (Oidium subgenus Pseudoidium) [1], Podosphaera xanthii (Sphaerotheca fusca; anamorph: Oidium subgenus Fibroidium) [2], and Erysiphe cucurbitacearum (Golovinomyces orontii; anamorph: Oidium subgenus Reticuloidium) [3]. For example, powdery mildew disease caused by Podosphaera xanthii (Schlechtend.:Fr.) Pollacci is a serious threat to melon plants in Japan [4] and in many parts of the world [5-12]. Moreover, powdery mildew fungi are the primary causes of agricultural problems that significantly reduce melon productivity and yield $[4,6,10,11,13]$. To solve this problem, physical [14], chemical [15], and biological [16-18] methods have been tested to control powdery mildew fungi on melons. In response, the fungi have become resistant to commercial fungi applied to plants [19-22]. As a result, new approaches to effectively control melon powdery mildew are urgently needed, particularly the development of eco-friendly methods for controlling powdery mildews from melon plants without the use of artificial agricultural chemicals. To this end, at first, powdery mildew fungi from the infected leaves of melons (Cucumis melo L. cv. Earl's Favourite) cultivated hydroponically in a greenhouse were isolated [23]. The isolate was identified based on morphological characteristics [6,24-26] and on the ribosomal DNA internal transcribed spacer (rDNA-ITS) sequences of cucurbit powdery mildew fungi $[27,28]$. The isolate was designated as Podosphaera xanthii (Schlechtend.:Fr.) Pollacci KMP-6N [2,23].

Normally, the isolate must be continuously maintained on host plants during experimental periods because powdery mildew fungi are obligate biotrophs. During the incubation of KMP-6N on host plants in a growth chamber under continuous illumination (22.2 $\left.\mu \mathrm{moL} \mathrm{m} \mathrm{m}^{-2} \mathrm{~s}^{-1}\right)$, a previous study found that KMP-6N formed continuous chains, often exceeding a length of seven conidia, without fully formed constrictions between the conidial cells [29]. By contrast, under greenhouse (natural environmental) conditions (190.6-400.4 $\mu \mathrm{moL} \mathrm{m}{ }^{-2} \mathrm{~s}^{-1}$ ), KMP-6N produced chains consisting of a maximum of six immature concatenated conidia, from which mature conidia were released [23]. Therefore, the environmental factors involved in constricting the conidial cells on conidiophores were investigated. The previous study demonstrated that the factors causing morphological changes in the conidiophores included light quality and wavelength [29]. In particular, KMP-6N colonies on melon leaves appeared flat under greenhouse conditions and red light-emitting diode (LED) irradiation but not growth chamber conditions and blue LED irradiation. In addition, the lengths of conidiophores in KMP-6N colonies cultured under greenhouse conditions and red light differed markedly from those cultured under growth chamber conditions and blue light; KMP-6N formed six concatenated conidia per conidiophore under greenhouse conditions and red light but more than seven conidia per conidiophore under growth chamber conditions and blue light. Furthermore, almost none of the conidia on the tops of conidiophores grown under growth chamber conditions and blue light were fully constricted, preventing these fungi from scattering their conidia. Therefore, further study underlying P. xanthii conidiophore responses to light at specific wavelengths (i.e., red and blue LEDs) and conidial scatter from conidiophores was recommended [29], particularly to explore whether the longer chains of unconstricted conidia observed in the previous study could maintain their germinative ability to infect host leaves.

Under environmental conditions, plant growth is influenced by light wavelength [30]. Recent studies have described the influence of different spectral qualities of light on the germination and development of cucurbit species [31,32]. The present study focused on the effects of red and blue LED irradiation on melon seedling growth and the spread of melon powdery mildew infection from a KMP-6N-infected melon seedling. Following previous observations, the current study assumed the protection of nursery-stage melon seedlings (from the cotyledon to 3-4 true leaf stages) against melon powdery mildew during short cultivation in a closed, temperature-controlled room, because KMP-6N scatters mature conidia from colonies to spread infection under natural conditions. In actuality, the number 
of conidia produced and released by single KMP- $6 \mathrm{~N}$ colonies over a period of 1 year using microscopic and electrostatic techniques was an average of $12.6 \times 10^{4}$ conidia at ca. $744 \mathrm{~h}$ (31 days) during the colony lifespan under natural conditions [33]. In the current cultivated systems, the uniformity of light quality and the distances of light irradiation were easily fixed to optimum levels for melon seedlings from 21 days after cotyledon development.

In the present study, previously developed electrostatic spore collectors, a dielectrically polarised insulator (ebonite) plate [34], and a probe [23,35,36] were used for investigating mature conidia collected from colonies and conidiophores under red and blue LED irradiation. To the best of our knowledge, this is the first study of the effects of red and blue LED light on the morphology of conidia forming chains on conidiophores, the initial time of mature conidia release from KMP- $6 \mathrm{~N}$ colonies (using microscopic and electrostatic techniques), melon seedling growth, and the spread of fungal diseases from a melon powdery mildew-infected melon seedling to surrounding healthy host seedlings over a 21 day experimental period. Data obtained in the present study give important insights into the ecological characteristics that suppress conidial scattering from melon powdery mildew colonies and may lead to the development of new methods for controlling melon powdery mildew in nursery production using blue LED irradiation.

\section{Materials and Methods}

\subsection{Plant Materials}

Melon (Cucumis melo L., cv. Earl's Favourite; F1 hybrid plants derived from a cross between Natsukei-1 gou and Natsukei-4 gou) seeds were obtained from Yuasa Experimental Farm, Kindai University (Wakayama, Japan; latitude $34.039^{\circ} \mathrm{N}$, longitude $135.19471^{\circ} \mathrm{E}$ and an altitude of $800 \mathrm{~m}$ ). The seeds were placed on wet filter paper in Petri dishes and germinated for 3-4 days in an LH-240N growth chamber (Nippon Medical and Chemical Instruments, Osaka, Japan) under continuous illumination $\left(22.2 \mu \mathrm{moL} \mathrm{m}^{-2} \mathrm{~s}^{-1} ; 380-750 \mathrm{~nm}\right)$ using white (full-spectrum) fluorescent lamps FL40SS W/37 (Mitsubishi, Tokyo, Japan) at $25 \pm 2{ }^{\circ} \mathrm{C}$. The germinated seedlings were placed on polyurethane cubic sponge supports $(3 \mathrm{~cm} \times 3 \mathrm{~cm} \times 3 \mathrm{~cm}$ ), inserted into $30 \mathrm{~mL}$ cylindrical plastic containers (diameter, $3 \mathrm{~cm}$; length, $5 \mathrm{~cm}$ ) containing $20 \mathrm{~mL}$ hydroponic nutrient solution $\left(4.0 \mathrm{mM} \mathrm{KNO}_{3}, 1.5 \mathrm{mM}\right.$ $\mathrm{Ca}\left(\mathrm{NO}_{3}\right)_{2}, 1.0 \mathrm{mM} \mathrm{MgSO}_{4}, 0.66 \mathrm{mM} \mathrm{NH}_{4} \mathrm{H}_{2} \mathrm{PO}_{4}, 0.057 \mathrm{mM}$ FeEDTA, $0.048 \mathrm{mM} \mathrm{H}_{3} \mathrm{BO}_{3}$, and $0.009 \mathrm{mM} \mathrm{MnSO}_{4}$ ) with a $\mathrm{pH}$ of $6.0-6.5$ and electrical conductivity of $1.2 \mathrm{mS} \mathrm{cm}^{-1}$ [23] and incubated for 14 days under controlled conditions $\left(25 \pm 1{ }^{\circ} \mathrm{C} ; 40-50 \%\right.$ relative humidity $[\mathrm{RH}]$; and continuous illumination of $\left.72.1 \mu \mathrm{moL} \mathrm{m}^{-2} \mathrm{~s}^{-1}\right)$. Then, the germinated seedlings were inserted into a multi-pack tray $(26 \mathrm{~cm} \times 26 \mathrm{~cm}$; height, $4.5 \mathrm{~cm})(49$ wells per tray), soaked in a set of hydroponic culture troughs $(44 \mathrm{~cm} \times 32 \mathrm{~cm}$; height, $6.5 \mathrm{~cm})$ containing $3 \mathrm{~L}$ hydroponic nutrient solution, and incubated for 7 days under the conditions described above. Seven-day-old melon seedlings were used to investigate powdery mildew spread. The solution was sampled $(10 \mathrm{~mL})$ every 3 days to normalise any deficient nutritional components in the solution. The present study was conducted at an experimental duration from April 2020 to November 2021.

\subsection{Fungal Materials}

The melon powdery mildew isolate Podosphaera xanthii Pollacci KMP-6N strain [23] was used in this study. Mature conidia were collected from conidiophores on KMP-6Ninfected melon leaves using a pencil-type electrostatic insulator probe. An ebonite rod with a pointed tip (length, $7 \mathrm{~cm}$; diameter, $4 \mathrm{~mm}$; tip diameter, $5 \mu \mathrm{m}$ ) was mounted on the micromanipulator of a high-fidelity digital microscope (KH-2700 DM, Hirox, Tokyo, Japan) and conidia were transferred onto the true leaves of healthy 14-day-old melon seedlings [23,36]. The isolate was maintained for 21 days by incubation in an electrostatic screen chamber (ES-chamber), which prevents the entry of airborne pathogens, installed in a greenhouse [37] and in an LH-240N growth chamber (Nippon Medical and Chemical Instruments) at $25 \pm 1{ }^{\circ} \mathrm{C}, 70-80 \% \mathrm{RH}$ under continuous illumination of $22.2 \mu \mathrm{moL} \mathrm{m}{ }^{-2} \mathrm{~s}^{-1}$. 
The voucher material of the KMP-6N fungus is preserved in the Herbarium Preservation Section of Kindai University (Nara, Japan).

\subsection{Microscopic Observation of Conidiophores in KMP-6N Colonies under Red or Blue LED Irradiation}

KMP-6N conidia were inoculated onto the true leaves of 14-day-old melon seedlings and then incubated for 10 days in an LH-240N growth chamber. The resulting 10-day-old KMP-6N colonies were transferred to two individual growth chambers $\left(25 \pm 1{ }^{\circ} \mathrm{C} ; 70-80 \%\right.$ $\mathrm{RH}$ ), equipped with red (ISL-150 $\times 150-\mathrm{H} 4 \mathrm{RR}$ ) or blue (ISL-150 $\times 150-\mathrm{BB} 45)$ LEDs (Creating Customer Satisfaction Inc., Kyoto, Japan) with red $(620-750 \mathrm{~nm}$; peak, $660 \mathrm{~nm})$ and blue spectra (450-495 nm; peak, $450 \mathrm{~nm}$ ). For each experimental treatment, the light intensity was measured using an LI-250A light meter (LI-COR, Tokyo, Japan) fitted with a quantum sensor that measures photosynthetically active radiation $(400-700 \mathrm{~nm})$. The seedlings were positioned at a distance of $30 \mathrm{~cm}$ from the LEDs. Light intensity was recorded facing the light source, at the top of the seedlings. The photon flux density (PFD) measurements were $16.4 \mu \mathrm{moL} \mathrm{m}{ }^{-2} \mathrm{~s}^{-1}$ for red LEDs and $14.8 \mu \mathrm{moL} \mathrm{m}{ }^{-2} \mathrm{~s}^{-1}$ for blue LEDs. The KMP$6 \mathrm{~N}$-infected melon seedlings were exposed to red or blue LED light for 2 days. Fungal colonies and the conidiophores irradiated with each LED light for a fixed period of time were observed using a KH-2700 DM and a BX-60 light microscope (BX-60 LM, Olympus, Tokyo, Japan). The single conidiophores were cut and collected with a tiny glass needle installed in a micromanipulator under the KH-2700 and inoculated artificially onto host leaves. Conidial germination and conidia chain development from conidiophores were observed using a KH-2700 DM and BX-60 LM, respectively.

For the histochemical staining of KMP-6N conidiophores, samples were prepared as follows: Leaf segments (approximately $1 \mathrm{~cm} \times 1 \mathrm{~cm}$ ) were cut from KMP-6N-inoculated seedlings and fixed. The chlorophyll of the leaf segments was removed in a boiling alcoholic lactophenol solution (10 mL glycerol, $10 \mathrm{~mL}$ phenol, $10 \mathrm{~mL}$ lactic acid, $10 \mathrm{~mL}$ distilled water, and $40 \mathrm{~mL} 99.8 \%$ ethanol) for 1-2 min, and then stained with $0.1 \%$ Aniline Blue (Nacalai Tesque, Tokyo, Japan) dissolved in distilled water, as previously described [38]. The samples were observed under a BX-60 LM.

\subsection{Collection of Progeny Conidia Released from Single KMP-6N Colonies Irradiated with Red or Blue LED Light}

Mature KMP-6N conidia were inoculated onto the well-developed young leaves of 14-day-old melon seedlings. The KMP-6N-inoculated seedlings were incubated in the LH240 growth chamber for 14 days under the conditions described above, and then transferred to three separate growth chambers $\left(25 \pm 1{ }^{\circ} \mathrm{C} ; 70-80 \% \mathrm{RH}\right)$ equipped with red or blue LED light sources or with white fluorescent lamps. The seedlings were positioned at a distance of $30 \mathrm{~cm}$ from the LEDs. For each experimental treatment, light intensity was measured under the conditions described above. The PFD of red LEDs was $16.4 \mu \mathrm{moL} \mathrm{m} \mathrm{m}^{-2} \mathrm{~s}^{-1}$, that of blue LEDs was $14.8 \mu \mathrm{moL} \mathrm{m}^{-2} \mathrm{~s}^{-1}$, and that of white fluorescent lamps was $22.2 \mu \mathrm{moL} \mathrm{m}^{-2} \mathrm{~s}^{-1}$. Melon seedlings with 14-day-old KMP-6N colonies were transferred to greenhouse (natural) conditions (190.6-400.4 $\mu \mathrm{moL} \mathrm{m}^{-2} \mathrm{~s}^{-1}$ ) as controls.

Conidia were collected using an electrostatic spore collector with an aluminium conductor plate $(60 \mathrm{~mm} \times 30 \mathrm{~mm})$ between two polyethylene terephthalate insulator plates $(80 \mathrm{~mm} \times 50 \mathrm{~mm})$ as previously described [34]. The conductor plate was connected to a direct current (DC) HVA 10K202PA voltage generator (Max Electronics, Tokyo, Japan). The surface of the insulator plate was negatively polarised by a current from the voltage generator. The insulator plate, charged with static electricity $\left(5.2 \times 10^{-1} \mathrm{nC}\right)$, was placed at a distance of $\sim 5000 \mu \mathrm{m}$ from the conidiophore apex to collect the released conidia, as previously described [29]. Conidia released from 10 individual colonies from each leaf in each experiment were collected electrostatically at definite intervals (0-48 h) under red or blue LED light or white fluorescent light irradiation or under greenhouse conditions and calculated using a KH-2700 DM. Data are presented as means and the standard deviation (SD) of 50 measurements. In addition, the conidia in each chain produced by 100 conidio- 
phores in colonies on each leaf were counted; the data are presented as means and SD of five replicates.

\subsection{Melon Cotyledon-Stage Seedling Growth under Red or Blue LED Irradiation}

Cotyledon-stage melon seedlings were incubated for 7 days in an LH-240 growth chamber under the conditions described above and then transferred to three separate growth chambers $\left(25 \pm 1{ }^{\circ} \mathrm{C}\right.$ and $\left.70-80 \% \mathrm{RH}\right)$ equipped with red or blue LED light sources or white fluorescent lamps. The seedlings were positioned at a $30 \mathrm{~cm}$ distance from the LEDs. For each experimental treatment, light intensity was measured under the conditions described above. The PFD of red LEDs was $16.4 \mu \mathrm{moL} \mathrm{m} \mathrm{m}^{-2} \mathrm{~s}^{-1}$, that of blue LEDs was $14.8 \mu \mathrm{moL} \mathrm{m}{ }^{-2} \mathrm{~s}^{-1}$, and that of white fluorescent lamps was $22.2 \mu \mathrm{moL} \mathrm{m}^{-2} \mathrm{~s}^{-1}$. Cotyledonstage melon seedlings were exposed to the light treatments for 15 days or transferred to the greenhouse (PFD, 190.6-400.4 $\mu \mathrm{moL} \mathrm{m}^{-2} \mathrm{~s}^{-1}$ ) to control for the effects of light on seedling development. In each experiment, stem length and leaf area (first to third true leaves) were measured, and true leaves were counted in 10 melon seedlings. The data are presented as means and SD of five replicates per treatment.

\subsection{Spread of Powdery Mildew from a KMP-6N-Infected Melon Seedling to Surrounding Healthy} Seedlings under Red or Blue LED Irradiation

Mature KMP-6N conidia were inoculated onto the well-developed young leaves of 14-day-old melon seedlings using the methods described above [23]. In each replicate, a KMP-6N-inoculated seedling was placed at the centre of a multi-pack tray, surrounded by 48 healthy 7-day-old melon seedlings, and maintained in a temperature-controlled room $\left(25 \pm 1{ }^{\circ} \mathrm{C} ; 45-55 \% \mathrm{RH}\right)$, with continuous illumination of $60 \mu \mathrm{moL} \mathrm{m}{ }^{-2} \mathrm{~s}^{-1}$ under red or blue LEDs or $22.2 \mu \mathrm{moL} \mathrm{m}{ }^{-2} \mathrm{~s}^{-1}$ under white fluorescent lamps. A continuous air current of $1.0 \mathrm{~m} \mathrm{~s}^{-1}$ [39] was provided to the seedlings using an electric fan positioned at a $1 \mathrm{~m}$ distance from the multi-pack tray. The current study photographed the 48 healthy seedlings at $24 \mathrm{~h}$ intervals using an EOS KISSX6i digital camera (Canon, Tokyo, Japan) and observed for 21 days to analyse the spread of powdery mildew to healthy melon seedlings. Finally, the fungal colonies appeared on leaves of cotyledon-stage seedlings at 21 days after treatments were checked with photographs and eyes.

\subsection{Statistical Analysis}

All experimental data are presented as means \pm standard deviations. Using EZR software version 1.54 (Jichi Medical University, Saitama, Japan), Tukey's test was performed to identify significant differences among conditions, as indicated in the figure and table legends.

\section{Results}

3.1. Development and Morphology of KMP-6N Colonies on Melon Leaves under Red or Blue LED Irradiation

The germination rates of KMP-6N conidia were approximately $30 \%$ on host leaves under irradiation by red and blue LEDs. KMP-6N conidia germinated on the melon leaves at $3-5 \mathrm{~h}$ and then produced appressoria at $6-8 \mathrm{~h}$ after inoculation. KMP-6N also began to produce secondary hyphae from the conidial bodies at $24 \mathrm{~h}$ after inoculation, and hyphae continued to elongate on the leaves. KMP- $6 \mathrm{~N}$ began to form conidiophores from elongated hyphae at 5-6 days after inoculation. The development of initial KMP-6N colonies stopped at approximately 21 days after inoculation and concentric colonies formed on the leaves. The development processes of fungal colonies under red and blue LED irradiation were similar to those under greenhouse and growth chamber control conditions. However, colonies irradiated with red or blue LED light were smaller in area than those grown under control conditions. The morphology of 12-day-old KMP- $6 \mathrm{~N}$ colonies grown for 2 days under red LED was flat (Figure 1A), whereas that of colonies grown for 2 days under blue LED was stacked (Figure 1B). Thus, detailed observation under the KH-2700 DM showed that KMP-6N colonies formed a maximum of six conidia per conidiophore under red LED 
(Figure 1C), whereas chains of greater than seven conidia per conidiophore formed under blue LED (Figure 1D). Histochemical staining of the same colonies followed by BX-60 LM and KH-2700 DM observation showed similar conidiophore morphology (Figure 1E,F). Thus, conidiophore length clearly differed between colonies grown under red and blue LEDs. Nearly all conidia on the tops of conidiophores grown under red LED were fully constricted at the joints between conidial cells, whereas those grown under blue LED were not fully constricted (Figure 1F,G). Eventually, the fungi were unable to scatter their conidia. Next, conidia that had formed on conidiophores in colonies grown for 2 days under red or blue LED were counted. The distribution of conidiophores with different numbers of conidia under each condition is shown in Figure 2. A maximum chain length of six conidia (seven conidia on rare occasions) was produced on conidiophores grown under red LED, whereas a maximum chain length of 22 conidia was produced under blue LED. Thus, the number of conidia piled up on conidiophores clearly differed between LED irradiation treatments, ultimately influencing conidiophore morphology. Next, the cytological characteristics of conidiophores irradiated with red or blue LEDs were examined. Histochemical treatment showed that conidia in chains on conidiophores under red LED were entirely stained (Figure 1E), whereas chains of seven or more conidia on conidiophores under blue LED showed staining only in the central parts of the conidia (Figure 1F,G). Conidiophores with fewer than six conidia per chain produced immature conidia that failed to germinate on various substrates including parafilm, glass slides, and host leaves (Figure 3A), whereas those with chains comprising more than seven conidia produced mature conidia that germinated on these substrates (Figure 3B-D). These germinated conidia infected host leaves, producing vigorously elongated hyphae (Figure 3E), and eventually generating many new conidiophores on the hyphae (Figure 3F).

\subsection{Conidia Collection from Colonies and Conidiophores under Red or Blue LED Irradiation}

All conidia released from single 14-day-old KMP-6N colonies using an electrostatic spore collector (i.e., an insulator plate) were collected, and the timing of initial conidial release under red or blue LED irradiation and under greenhouse or growth chamber conditions (as controls) were examined. Only conidia that were fully constricted on the conidiophores were collected onto the plate when the insulators were negatively polarised. The number of conidia collected from single colonies under each irradiation condition is listed in Table 1 and those remaining in chains on the conidiophores after collection with the electrostatic insulator plate are listed in Table 2. Large numbers of conidia were attracted from the colonies onto the plate under red irradiation and greenhouse conditions; these numbers increased gradually with increasing irradiation time. The initial time of conidia released from the colonies was between 2 to $4 \mathrm{~h}$ after the start of red irradiation and greenhouse conditions (Table 1). By contrast, few conidia were attracted onto the electrostatic insulator plate from colonies under blue irradiation or growth chamber conditions, and these numbers remained stable as the irradiation time increased to $48 \mathrm{~h}$ (Table 1). The numbers of conidia remaining piled up on the conidiophores after collection with the electrostatic collector are listed in Table 2, showing a gradual decrease under red irradiation and greenhouse conditions, leading to the gradual shortening of the conidiophores with time, whereas the numbers of conidia remaining piled up on the conidiophores after electrostatic collection increased under blue irradiation and growth chamber conditions, with conidiophores lengthening over time. Eventually, colonies under red illumination were shorter than those under blue irradiation (Figure 1A,B). The morphology of the KMP-6N colony under greenhouse and growth chamber conditions was the same as that under red LED and blue LED irradiation, respectively. 


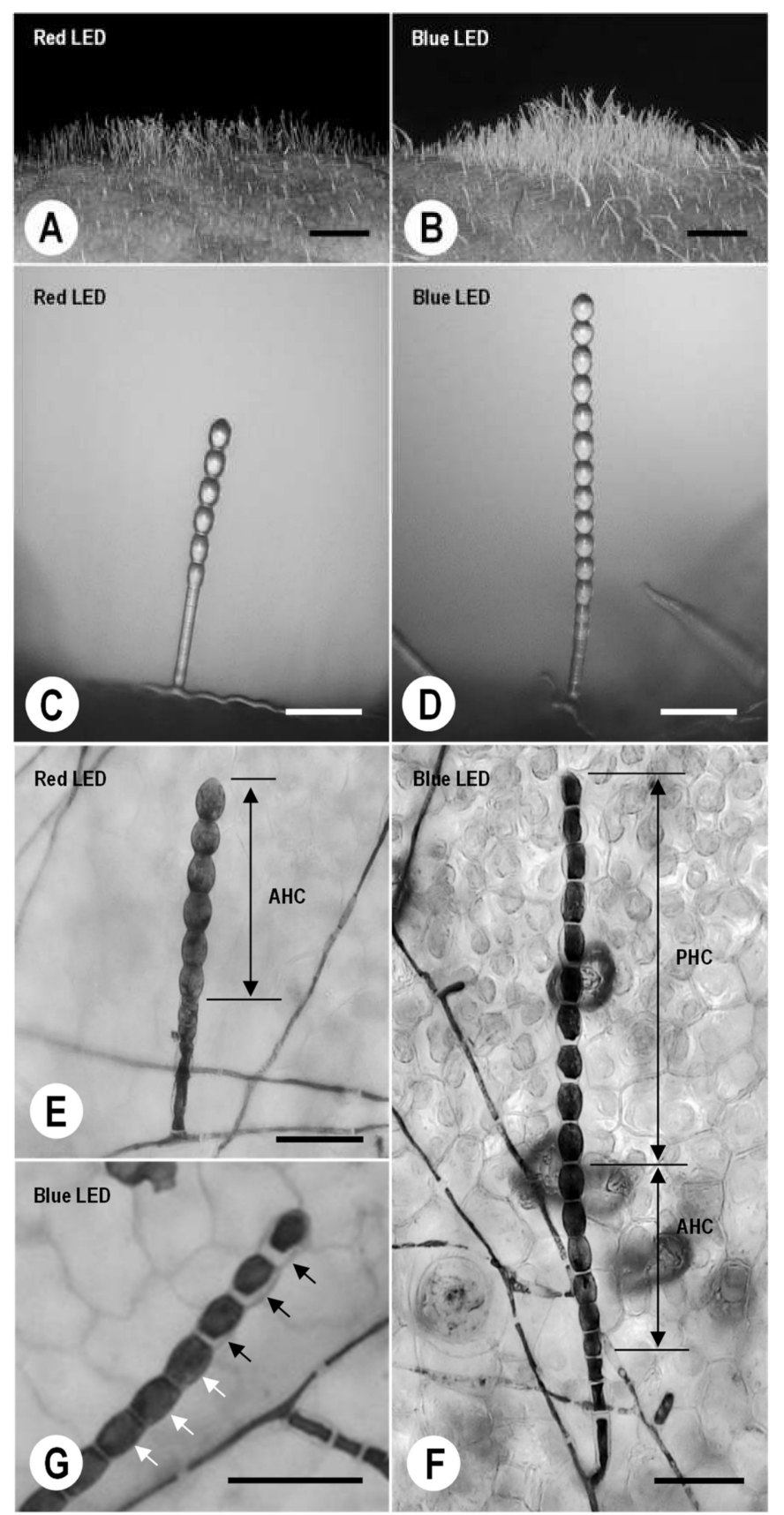

Figure 1. Morphological characteristics of Podosphaera xanthii (Schlechtend.:Fr.) Pollacci KMP-6N colonies and conidiophores on the leaves of melon plants irradiated under red $(\mathrm{A}, \mathrm{C}, \mathrm{E})$ and blue $(\mathbf{B}, \mathbf{D}, \mathbf{F}, \mathbf{G})$ light-emitting diodes (LEDs). (A,B) Digital micrographs of 12-day-old KMP-6N colonies grown under red LEDs (A) were shorter than those grown under blue LEDs (B). (C,D) Digital micrographs of full-length chains of six (C) and 12 concatenated conidia (D). (E-G) Light micrographs of short (E) and long catenated conidia (F), and upper parts of long chains of catenated conidia (G) observed after histochemical staining. In chains consisting of six or fewer conidial cells, entire conidia were stained (AHC) in (E), whereas in chains consisting of more than seven conidial cells, only the central parts of the conidial cells were stained (PHC) in (F). In unconstricted conidial cells at the upper parts of conidiophores shown in $(\mathbf{G})$, only the central parts of the conidial cells were stained (black arrows), whereas the cells below were entirely stained (white arrows). These micrographs were taken 12 days after inoculation with KMP-6N conidia. Bars represent $500 \mu \mathrm{m}(\mathbf{A}, \mathbf{B})$, and $50 \mu \mathrm{m}(\mathbf{C}-\mathbf{G})$. 


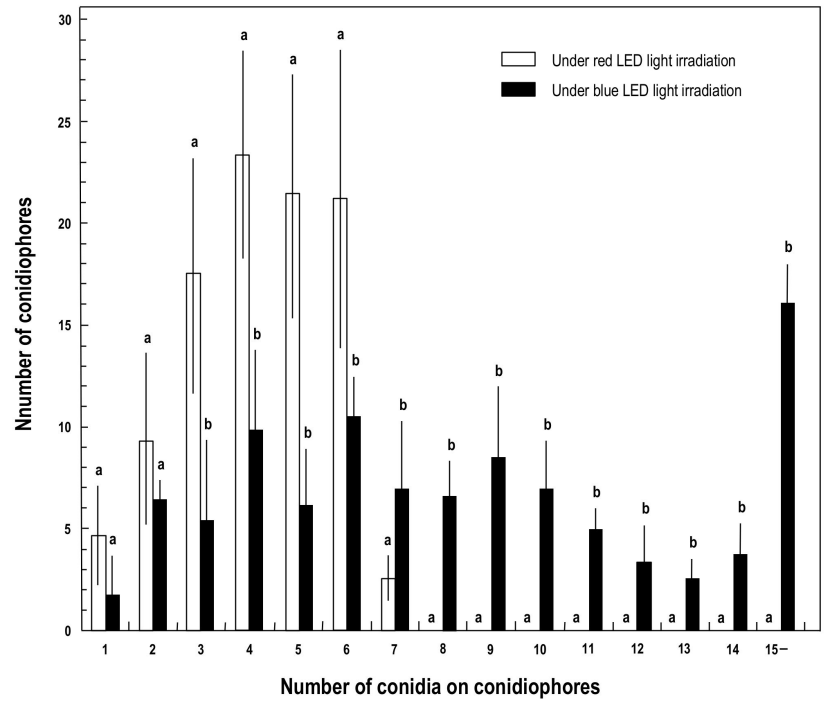

Figure 2. Frequency distribution of conidiophores with different numbers of conidia under red and blue LED irradiation. Conidiophores were counted in 12-day-old KMP-6N colonies, incubated for 10 days under growth chamber conditions and then for 2 days under red or blue LED irradiation. The numbers in the axis mean the number of conidia piled in chains on conidiophores. KMP-6N did not pile more than eight conidia in chains on conidiophores under red LED light irradiation while more were piled under blue LED light irradiation. Data are means \pm standard deviations (SDs) of five replicates. Different letters (a and $b$ ) indicate significant differences $(p<0.05$, Tukey's test).

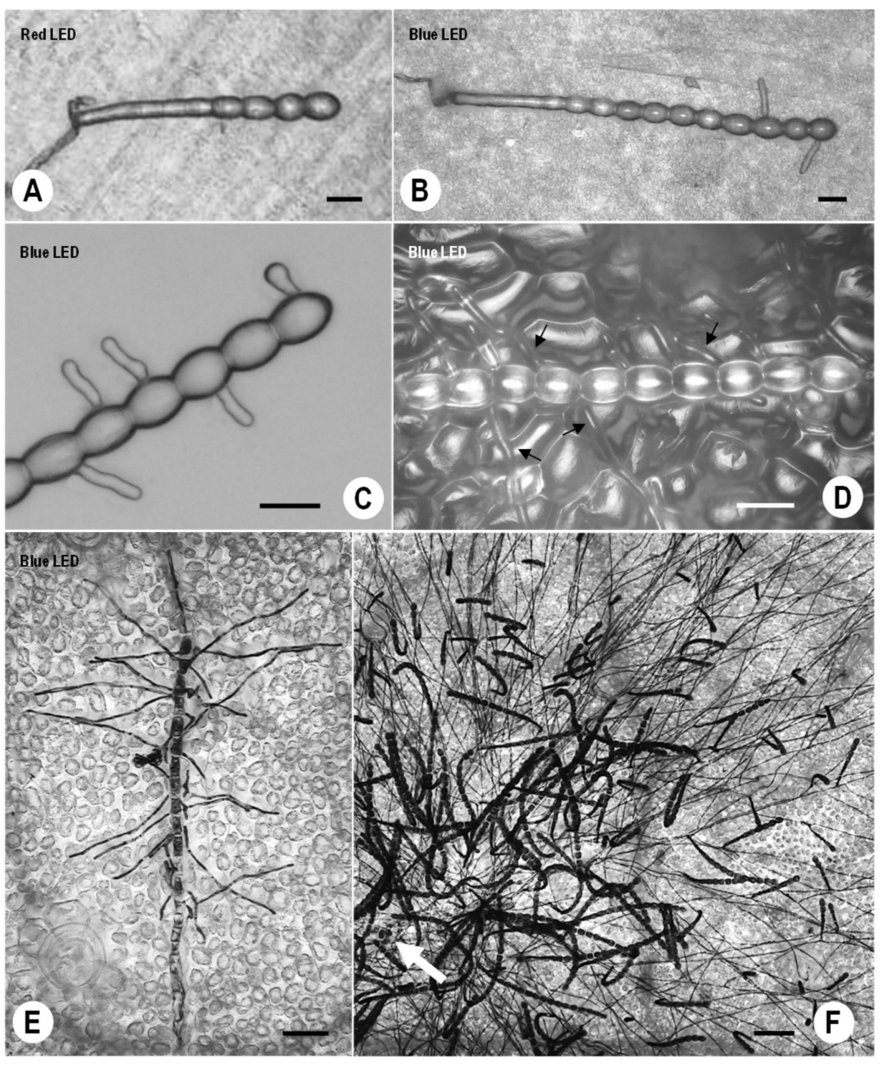

Figure 3. Comparison of conidial germination and fungal development between KMP-6N conidiophores under red (A) and blue LED irradiation (B-F). (A-D) Digital micrographs of conidiophores irradiated under red (A) or blue light (B) and then inoculated onto parafilm. Conidiophores exposed 
to blue light were inoculated onto glass slides (C) and melon seedling leaves (D). Conidial cells on conidiophores irradiated under blue light germinated onto each substrate, whereas those irradiated under red light did not. Black arrows indicate germ tubes formed from conidial cells on conidiophores in (D). (E,F) Light micrographs of hyphae elongated from conidiophores (E) and abundant, newly formed conidiophores (F) onto leaves of melon seedlings after histochemical staining. The white arrow indicates the inoculation site of a conidiophore comprising 10 conidial cells in chains in (F). These micrographs were taken 1 day $(\mathbf{A}-\mathbf{C}), 2$ days (D), 3 days $(\mathbf{E})$, and 10 days $(\mathbf{F})$ after the inoculation of KMP-6N conidiophores. Bars represent $20 \mu \mathrm{m}(\mathbf{A}-\mathbf{D}), 40 \mu \mathrm{m}(\mathbf{E})$, and $150 \mu \mathrm{m}(\mathbf{F})$.

Table 1. Number of progeny conidia collected from single Podosphaera xanthii (Schlechtend.:Fr.) Pollacci KMP-6N colonies using an electrostatic spore collector (insulator plate).

\begin{tabular}{|c|c|c|c|c|c|c|c|c|c|c|c|}
\hline \multirow{2}{*}{$\begin{array}{l}\text { Conditons for } \\
\text { Incubation }\end{array}$} & \multicolumn{11}{|c|}{ The Irradiation Time } \\
\hline & 0 & 2 & 4 & 6 & 12 & 18 & 24 & 30 & 36 & 42 & 48 \\
\hline Greenhouse & $0 x$ & $2.8 \pm 0.9 x$ & $8.3 \pm 5.4 x$ & $11.0 \pm 7.0 \mathrm{x}$ & $13.7 \pm 5.3 x$ & $13.5 \pm 4.5 \mathrm{x}$ & $42.7 \pm 9.4 x$ & $107.0 \pm 17.0 x$ & $298.4 \pm 60.6 x$ & $472.8 \pm 51.2 x$ & $712.9 \pm 124.2 \times$ \\
\hline Growth chamber & $0 \mathrm{x}$ & $0 \mathrm{y}$ & $1.0 \pm 0.5 \mathrm{y}$ & $1.2 \pm 1.2 \mathrm{y}$ & $0.9 \pm 0.9 \mathrm{y}$ & $1.0 \pm 1.0 \mathrm{y}$ & $0.7 \pm 0.4 \mathrm{y}$ & $1.3 \pm 0.9 \mathrm{y}$ & $1.4 \pm 0.7 \mathrm{y}$ & $1.7 \pm 1.2 \mathrm{y}$ & $1.5 \pm 1.4 \mathrm{y}$ \\
\hline Red LED-lights & $0 x$ & $0.2 \pm 0.2 \mathrm{y}$ & $0.6 \pm 0.6 \mathrm{y}$ & $10.8 \pm 5.6 x$ & $16.2 \pm 4.9 \mathrm{x}$ & $17.2 \pm 7.7 x$ & $25.9 \pm 11.7 x$ & $93.5 \pm 47.2 x$ & $329.0 \pm 123.2 x$ & $423.3 \pm 100.9 x$ & $657.2 \pm 170.1 \times$ \\
\hline Blue LED-lights & $0 \mathrm{x}$ & $0 \mathrm{y}$ & $0.4 \pm 0.2 \mathrm{y}$ & $1.1 \pm 1.1 \mathrm{y}$ & $1.2 \pm 1.2 \mathrm{y}$ & $1.8 \pm 1.8 \mathrm{y}$ & $1.7 \pm 1.7 \mathrm{y}$ & $1.1 \pm 0.7 \mathrm{y}$ & $1.0 \pm 1.0 \mathrm{y}$ & $1.4 \pm 1.2 \mathrm{y}$ & $1.2 \pm 1.2 \mathrm{y}$ \\
\hline
\end{tabular}

Different letters in each column indicate significant differences ( $p<0.05$, Tukey's test).

Table 2. Number of conidia remaining on KMP-6N conidiophores following the collection of progeny conidia using an electrostatic spore collector (insulator plate).

\begin{tabular}{|c|c|c|c|c|c|c|c|c|c|c|c|}
\hline \multirow{2}{*}{$\begin{array}{l}\text { Conditons for } \\
\text { Incubation }\end{array}$} & \multicolumn{11}{|c|}{ The Irradiation Time } \\
\hline & 0 & 2 & 4 & 6 & 12 & 18 & 24 & 30 & 36 & 42 & 48 \\
\hline Greenhouse & $12.8 \pm 1.2 \mathrm{x}$ & $12.2 \pm 1.8 \mathrm{x}$ & $13.1 \pm 0.4 \mathrm{x}$ & $14.3 \pm 1.1 \mathrm{x}$ & $13.7 \pm 1.0 x$ & $13.1 \pm 1.6 x$ & $8.2 \pm 1.0 \mathrm{x}$ & $6.8 \pm 0.6 \mathrm{x}$ & $6.7 \pm 0.9 x$ & $7.1 \pm 0.5 x$ & $7.0 \pm 0.5 x$ \\
\hline Growth chamber & $12.9 \pm 1.0 \mathrm{x}$ & $13.7 \pm 1.8 \mathrm{x}$ & $13.6 \pm 2.0 x$ & $14.4 \pm 0.8 \mathrm{x}$ & $15.6 \pm 0.6 \mathrm{y}$ & $15.7 \pm 1.0 \mathrm{y}$ & $16.6 \pm 1.3 \mathrm{y}$ & $17.2 \pm 0.6 \mathrm{y}$ & $17.4 \pm 0.5 \mathrm{y}$ & $18.9 \pm 0.9 \mathrm{y}$ & $19.0 \pm 1.7 \mathrm{y}$ \\
\hline Red LED-lights & $12.3 \pm 0.9 x$ & $12.6 \pm 2.0 x$ & $13.4 \pm 1.9 x$ & $14.2 \pm 1.7 x$ & $14.1 \pm 0.8 \mathrm{x}$ & $12.4 \pm 0.7 x$ & $8.9 \pm 1.0 x$ & $7.2 \pm 0.9 x$ & $6.4 \pm 0.6 \mathrm{x}$ & $7.2 \pm 0.9 x$ & $6.9 \pm 0.8 \mathrm{x}$ \\
\hline Blue LED-lights & $12.4 \pm 0.7 x$ & $13.4 \pm 0.7 x$ & $13.7 \pm 1.5 x$ & $14.9 \pm 1.9 x$ & $15.8 \pm 0.8 \mathrm{y}$ & $16.2 \pm 0.8 \mathrm{y}$ & $16.0 \pm 0.6 \mathrm{y}$ & $17.1 \pm 0.7 \mathrm{y}$ & $17.9 \pm 1.2 \mathrm{y}$ & $18.4 \pm 0.8 \mathrm{y}$ & $20.6 \pm 1.4 \mathrm{y}$ \\
\hline
\end{tabular}

Different letters in each column indicate significant differences ( $p<0.05$, Tukey's test).

\subsection{Effects of Red and Blue LED Light Irradiation on Cotyledon-Stage Melon Seedling Development}

The current study examined the effects of red and blue LED treatments on the development of cotyledon-stage melon seedlings. Seven-day-old cotyledon-stage melon seedlings were continuously exposed to red or blue irradiation in an LH-240 growth chamber or placed under greenhouse or growth chamber control conditions and incubated for 15 days. Seedling stems grew gradually under all conditions (Figure 4), with no significant differences until 7 days after treatment. At 8 days, significant differences in stem length were observed between red or blue irradiation and greenhouse or growth chamber control conditions. The stem length, leaf number, and leaf area (first to third true leaves) of each seedling are listed in Table 3 . The leaf number and leaf area significantly differed between seedlings grown under red and blue irradiation conditions.

\subsection{Spread of Powdery Mildew from a KMP-6N-Infected Melon Seedling to Healthy Melon Seedlings}

The current study examined the spread of melon powdery mildew infections originating from a single KMP-6N-infected melon seedling under red or blue LED irradiation. Faint KMP-6N colonies were initially observed on the leaves of healthy melon seedlings at $\sim 6$ days under red light and greenhouse conditions, followed by gradual spread of the disease to surrounding melon seedlings, whereas the same pattern started at $~ 12$ days under blue light, with very little expansion of the disease to the surrounding healthy melon seedlings, and growth chamber conditions, with little expansion of the disease to the healthy melon seedlings. Once infected, almost all seedlings showed powdery mildew symptoms until $\sim 21$ days under red irradiation and greenhouse conditions, whereas only seedlings near the KMP-6N-infected seedling showed symptoms under blue irradiation (Figure 5). Thus, the spread of powdery mildew to surrounding healthy melon seedlings clearly differed between the red and blue treatments. 




Figure 4. Continuous changes in melon seedling development from the cotyledon to three-true unfolded leaves stages during irradiation under red or blue LEDs. Melon seedlings grown under greenhouse and growth chamber conditions were used as controls. Stem length was measured repeatedly in the same melon seedlings treated under each condition for a period of 15 days. The black arrow indicates days showing significant differences in melon seedling growth among the four seedling groups. Data are means \pm SDs of five replicates. Different letters indicate significant differences ( $p<0.05$, Tukey's test).

Table 3. Effects of light quality on melon seedling growth under irradiation with red or blue light for 15 days.

\begin{tabular}{cccccc}
\hline \multirow{2}{*}{$\begin{array}{c}\text { Conditons for } \\
\text { Incubation }\end{array}$} & Stem Lengths $\mathbf{( c m )}$ & The Number of Leveas & \multicolumn{3}{c}{ Unfolded Leaf Areas $\left(\mathbf{m m}^{\mathbf{2}}\right)$} \\
\cline { 3 - 6 } & & & First & Second & Third \\
\hline Greenhouse & $3.5 \pm 1.1 \mathrm{x}$ & $2.8 \pm 0.4 \mathrm{x}$ & $910.0 \pm 394.0 \mathrm{x}$ & $839.1 \pm 436.1 \mathrm{x}$ & $785.7 \pm 231.8 \mathrm{x}$ \\
Growth chamber & $3.2 \pm 1.3 \mathrm{x}$ & $3.0 \pm 0.6 \mathrm{x}$ & $963.0 \pm 423.6 \mathrm{x}$ & $923.8 \pm 575.3 \times$ & $888.6 \pm 488.1 \mathrm{x}$ \\
\hline Red LED-lights & $2.2 \pm 0.6 \mathrm{y}$ & $2.6 \pm 0.6 \mathrm{x}$ & $845.9 \pm 466.8 \mathrm{x}$ & $834.8 \pm 384.4 \mathrm{x}$ & $829.5 \pm 540.0 \mathrm{x}$ \\
Blue LED-lights & $1.6 \pm 0.5 \mathrm{y}$ & $2.5 \pm 0.6 \mathrm{x}$ & $705.3 \pm 400.2 \mathrm{x}$ & $495.0 \pm 276.5 \mathrm{y}$ & $490.4 \pm 228.9 \mathrm{y}$ \\
\hline
\end{tabular}

Different letters in each column indicate a significant difference $(p<0.05$, Tukey's method).

A

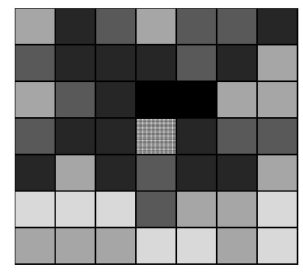

C
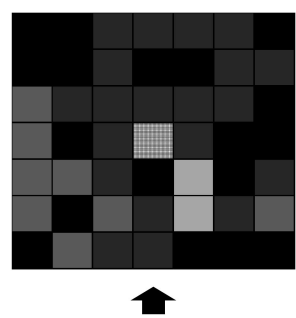

B

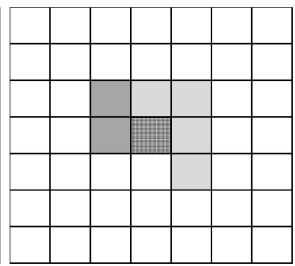

D

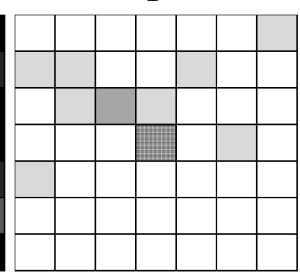

Figure 5. Distribution of melon powdery mildew infection spread by conidial scatter from a single KNP-6N-inoculated melon seedling to surrounding healthy melon seedlings under continuous red 
(A) or blue light (B) irradiation or under greenhouse (C) or growth chamber (D) conditions (controls) during a 21-day experimental period. Data are numbers of diseased melon seedlings; no symptoms ( $\square), 1(\square), 2(\square), 3(\square), 4$ ( $\square$ ), and 5 diseased $(\square)$ melon seedlings of 5 tested melon seedlings, respectively. Columns represent the positions of KMP-6N-infected (曲) and healthy melon seedlings initially planted for the experiment. Black arrows indicate wind direction (velocity, $1.0 \mathrm{~m} \mathrm{~s}^{-1}$ ) from an electric fan to a multi-pack tray. The fungal colonies appeared on leaves of cotyledon-stage seedlings at 21 days after treatments were checked with photographs and eyes. Each experiment was replicated five times, and the distribution of the infection spread included all data from five tests at 21 days after treatments.

\section{Discussion}

Previous studies have described the inhibitory effects of specific light wavelengths on the developments (e.g., conidial germination or mycelial growth) of powdery mildew fungi on cucumbers (P. xanthii Pollacci) [40-45], tomatoes (Pseudoidium neolycopersici L. Kiss) [46], grapevines (Erysiphe necator Burrill) [47], strawberries (P. aphanis Braun and Takamatsu) [48,49], and roses (P. pannosa de Bary) [44,50-52]. These studies have typically used visible (e.g., red, blue, and green) light, ultraviolet-A (UV-A, 300-420 nm), ultravioletB (UV-B, 280-300 nm), and fluorescent illumination treatments with a high red-to-farred ratio (R:FR, red [600-700 nm] and far-red [700-800 nm] wavelengths). The present study conducted detailed analyses of differences in the morphological and cytological characteristics of conidiophores under two visible light sources: red and blue LEDs. The previous study observed the morphology of $P$. xanthii KMP-6N colonies grown on host leaves under red or blue LED irradiation, as well as under greenhouse (natural) and growth chamber conditions, and found that colonies formed under red light and natural conditions clearly differed morphologically from those formed under blue light and growth chamber conditions in several aspects: fungal colonies on leaves were flat (stacked) under red light and natural conditions (blue light and growth chamber conditions), conidiophores under blue light and growth chamber conditions were remarkably longer than those under red light and natural conditions, and conidiophores in colonies under red light and natural conditions formed chains made up of a maximum of six conidia, whereas chains formed under blue light and growth chamber conditions had more than seven conidia [29]. The current study also found that KMP-6N continued to produce conidia (up to 40 conidia) on conidiophores under blue light, without releasing them from the conidiophores. The present study also demonstrated the formation of unconstricted melon powdery mildew conidia (up to 40 conidia) in chains on conidiophores under blue irradiation, rather than the repeated release of conidia. By contrast, Takikawa et al. [23] reported that KMP-6N produced $\sim 36-40$ conidia per conidiophore during its lifetime under natural conditions; using a combination of digital microscopic and electrostatic techniques, the previous study found that the fungi released 34-38 mature conidia and retained two immature conidia on the conidiophore. Thus, the current study demonstrated that conidiophores under blue irradiation released nearly the same number of conidia in chains as they might otherwise release throughout their entire lifetime under natural conditions. On the other hand, among other powdery mildew fungi (Ps. neolycopersici L. Kiss KTP-01 and Blumeria graminis f. sp. hordei Marchal race1 KBP-01), the number of conidia formed on conidiophores was the same under red and blue light irradiation; KTP-01 formed single, non-catenated conidia on conidiophores $[39,53]$, whereas KBP-01 formed a maximum of eight concatenated conidia per chain [35] under a $1.0 \mathrm{~m} \mathrm{~s}^{-1}$ air current, as in the present study. Therefore, the current study concludes that the formation of KMP-6N conidiophores has been influenced by specific light wavelengths.

The current study also examined the morphological and cytological characteristics of unconstricted conidia in chains on the conidiophores and found that the joints between conidial cells on conidiophores were completely divided by septa. Conidia are usually released from conidiophores after constriction by the septa between conidial cells at the 
top of the conidiophores [23]. Interestingly, histochemical treatment showed that prior to conidia release, conidia in chains on conidiophores under red LED light irradiation were entirely stained (see Figure 1E), whereas those on chains of seven or more conidia under blue irradiation were stained only in the central parts of conidial cells (see Figure 1F,G). Conidia in chains on conidiophores germinated in a connected state on the substrates and successfully infected the host leaves (see Figure 3). This indicated that conidia in chains of more than seven that were piled up on conidiophores retained their germination ability; therefore, cytoplasm aggregation centralised in conidial cells appears to be an indicator of germinative mature conidia. Thus, KMP-6N appears to complete its lifetime production of progeny conidia on conidiophores, without releasing germinative and infective mature conidia, under blue LED irradiation conditions. The current study also found that KMP-6N begins to release mature progeny conidia from conidiophores after 2 to $4 \mathrm{~h}$ of red irradiation, such that KMP-6N conidiophores are photosensitive to specific light wavelengths for the release of progeny conidia from conidiophores. From this knowledge, next, the effects of red and blue irradiation on cotyledon-stage melon seedling growth and the spread of powdery mildew disease among healthy melon seedlings were examined.

Blue light is involved in a wide range of plant developmental processes such as phototropism, photomorphogenesis, stomatal opening, and leaf photosynthetic function [54]. Previous studies have compared plants grown under blue or a combination of red and blue light with those grown under red light to assess blue light effects on the leaf or wholeplant level [55-57]. Recently, Schmidt et al. [31] studied the influence of different spectral qualities of light on the germination and vigour of cucurbit (cucumber, melon, and watermelon) seeds. The current study examined the influence of red and blue LED irradiation on cotyledon-stage seedling development because our main objective was to evaluate the suppressive effects of light on the spread of powdery mildew infection in melon nursery gardens. However, blue light inhibited the growth of cotyledon-stage seedlings compared to the control (natural and growth chamber) conditions. Therefore, cryptochrome function appears to be dramatically affected by blue irradiation, as described by Taiz et al. [58]. The current study concluded that it may not be necessary to irradiate seedlings under a combination of red and blue LEDs because continuous blue irradiation at a fixed period of 7 days had no influence on seedling growth in the nursery. Even if seedling growth slowed at $>8$ days of blue irradiation compared to control conditions, dwarf seedlings grow normally after planting in a natural environment. However, conidial germination rates were lower under blue light $(\sim 30 \%$ after $24 \mathrm{~h})$ than under control conditions $(\sim 70 \%)$ [29]. The current study also demonstrated that few KMP-6N conidia were released from single powdery mildew colonies under blue light and growth chamber conditions compared to red light and natural conditions. Eventually, almost no infection spread (secondary infection to neighbouring healthy melon seedlings) occurred under blue irradiation for fixed periods of time during the 21 day experimental period, and only slight infection spread (secondary infection to healthy melon seedlings) occurred under growth chamber conditions. Thus, the spread of KMP-6N to healthy melon seedlings differed between blue and white light irradiation. In the future, why differences in the infection spread of KMP-6N between both light irradiations occur will be clarified. Powdery mildew-free seedlings raised under blue irradiation could potentially be used for planting under natural conditions. Altogether, the current study has clearly indicated that KMP-6N conidiophores have receptors for specific light wavelengths, to which they respond by constricting conidial cells at the tops of conidiophores; constriction between conidial cells appeared to be induced under red, but not blue, LED irradiation.

Wang et al. [41] reported that red light exposure suppresses the development of cucumber powdery mildew (Podosphaera xanthii) on host plants and that fungal development on host plants is inhibited by continuous red light irradiation in a manner involving the production of $\mathrm{H}_{2} \mathrm{O}_{2}$ and salicylic acid and the expression of defence-related genes (including PR-1) in host plants. The previous study reported that the continuous exposure of KMP-6N-inoculated melon seedlings to red or blue light inhibits fungal development 
compared to greenhouse and growth chamber conditions [29]. Thus, melon plants irradiated with blue light appear to produce factors involved in disease resistance, similar to those produced under red light irradiation, as reported by Wang et al. [41]. Moreover, once KMP-6N form conidiophores in colonies under continuous red light irradiation, it may be difficult to completely inhibit the spread of powdery mildew infection to healthy host seedlings because mature conidia are actively scattered from conidiophores compared to blue light irradiation (see Table 1 ).

The present study is the first report to describe the morphological changes and cytological characteristics of conidia in chains on conidiophores under red and blue light irradiation and the effects of red and blue light on the spread of powdery mildew from a single infected melon seedling to surrounding healthy seedlings. The results obtained in this study are useful for elucidating the physiological characteristics of melon powdery mildew conidiophores that release mature conidia. As a next step, the related gene expression and fungal cell (septum) structures that cause non-constriction between conidial cells at the tops of conidiophores will be analysed at the molecular and cytological levels. Future studies will elucidate the ecological mechanisms of the release of progeny conidia from melon powdery mildew conidiophores.

\section{Conclusions}

The conidiophore morphology of melon powdery mildew KMP-6N clearly differed under red or blue light irradiation; a maximum of six conidia was piled up on each conidiophore under red light, compared to more than seven conidia per conidiophore under blue light. In addition, the conidia on the tops of conidiophores were constricted under red light but not fully constricted under blue light. Following the inoculation of conidiophores with more than seven conidia per chain onto host leaves, unconstricted conidial cells on the conidiophores germinated on infected host leaves and grew vigorously. Under red light, gradually increasing numbers of conidia were collected using electrostatic techniques with irradiation time. Initial conidial release from single colonies occurred at between 2 to $4 \mathrm{~h}$ and the number of conidia remaining on conidiophores gradually decreased, shortening the conidiophores. By contrast, under blue light, few conidia were collected at any time and the number of conidia on conidiophores gradually increased with irradiation time, lengthening the conidiophores and eventually preventing the fungi from significantly scattering their conidia. Finally, the effects of red or blue light on the spread of KMP-6N infection to surrounding healthy seedlings were examined. Consequently, nearly all seedlings showed symptoms within 21 days of red light irradiation, whereas only seedlings near the single infected seedling showed symptoms after blue light irradiation. Thus, the spread of KMP-6N infection clearly differed under red or blue light irradiation. Future studies will analyse the expression of genes related to the non-constriction between conidial cells at the tops of conidiophores caused by blue light irradiation.

Author Contributions: Conceptualisation, T.S. and T.N.; methodology, T.S., Y.M. and T.N.; software, S.I. and Y.T.; validation, Y.M., K.K. and T.N.; formal analysis, T.S. and S.I.; investigation, T.S., H.H., A.M. and H.O.; resources, T.S. and T.N.; data curation, T.S. and T.N.; writing-original draft preparation, T.S. and T.N.; writing-review and editing, T.N.; visualization, Y.M. and T.N.; supervision, T.N.; project administration, T.N. All authors have read and agreed to the published version of the manuscript.

Funding: This research received no external funding.

Institutional Review Board Statement: Not applicable.

Informed Consent Statement: Not applicable.

Data Availability Statement: Data sets analysed during the current study are available from the current author on reasonable request. 
Acknowledgments: This work was supported by a Grant for Agriculture Technology and Innovation Research Institute, Kindai University. In addition, the English in this document has been checked by at least two professional editors, both native speakers of English.

Conflicts of Interest: The authors declare no conflict of interest.

\section{References}

1. Sato, Y.; Nakamura, T.; Takamatsu, S.; Morikawa, T.; Chikuo, Y. Powdery mildew fungi newly found on Datura stramonium and Cucumis sativus in Japan (abstract in Japanese). Ann. Phytophathol. Soc. Jpn. 1996, 62, 630.

2. Braun, U.; Shishkoff, N.; Takamatsu, S. Phylogeny of Podosphaera sect. Sphaerotheca subsect. Magnicellulatae (Sphaerotheca fuliginea auct. s. lat.) inferred from rDNA ITS sequences-A taxonomic interpretation. Schlechtendalia 2001, 7, 45-52.

3. Uchida, K.; Takamatsu, S.; Matsuda, S.; So, K.; Sato, Y. Morphological and molecular characterization of Oidium subgenus Reticuloidium (powdery mildew) newly occurred on cucumber in Japan. J. Gen. Plant Pathol. 2009, 75, 92-100. [CrossRef]

4. Hosoya, K.; Narisawa, K.; Pitrat, M.; Ezura, H. Race identification in powdery mildew (Sphaerotheca fuliginea) on melon (Cucumis melo) in Japan. Plant Breeding 1999, 118, 259-262. [CrossRef]

5. Sowell, G., Jr. Population shift of Sphaerotheca fuliginea on musk melon. J. Am. Soc. Hortic Sci. 1982, 112, $156-160$.

6. Reifschneider, F.J.B.; Boiteux, L.S.; Occhiena, E.M. Powdery mildew on melon (Cucumis melo) caused by Sphaerotheca fuliginea in Brazil. Plant Dis. 1985, 69, 1069-1070.

7. Mohamed, Y.F.; Bardin, M.; Nicot, P.C.; Pitrat, M. Causal agents of powdery mildew of cucurbits in Sudan. Plant Dis. 1995, 79, 634-636. [CrossRef]

8. Del Pino, D.; Olalla, L.; Pérez-García, A.; Rivera, M.E.; García, S.; Moreno, R.; Torés, J.A. Occurrence of races and pathotypes of cucurbit powdery mildew in southeastern Spain. Phytoparasitica 2002, 30, 459-466. [CrossRef]

9. Křístková, E.; Lebeda, A.; Sedláková, B. Virulence of Czech cucurbit powdery mildew isolates on Cucumis melo genotypes MR-1 and PI 124112. Sci. Hortic. 2004, 99, 257-265. [CrossRef]

10. Tomason, Y.; Gibson, P.T. Fungal characteristics and varietal reactions of powdery mildew species on cucurbits in steppes of Ukraine. Agron. Res. 2006, 4, 549-562.

11. Pérez-García, A.; Romero, D.; Fernández-Ortuño, D.; López-Ruiz, F.; De Vicente, A.; Torés, J.A. The powdery mildew fungus Podosphaera fusca (synonym Podosphaera xanthii), a constant threat to cucurbits. Mol. Plant Pathol. 2009, 10, 153-160. [CrossRef]

12. Hong, Y.-J.; Hossain, M.R.; Kim, H.-T.; Park, J.-I.; Nou, I.-S. Identification of two new races of Podosphaera xanthii causing powdery mildew in melon in South Korea. Plant Pathol. J. 2018, 34, 182-190. [CrossRef]

13. McGrath, M.T.; Thomas, C.E. Powdery mildew. In Compendium of Cucurbit Disease; The American Phytopathological Society Press: St. Paul, MN, USA, 1996; pp. 28-30.

14. Munger, H.M. The influence of temperature on powdery mildew resistance in cucumber. Cucurbit Genet. Coop. Rep. 1979, 2, 9-10.

15. Matheron, M.E.; Porchas, M. Comparative performance and preservation of chemical management tools for powdery mildew on muskmelon. Acta Hortic. 2007, 731, 357-361. [CrossRef]

16. Krístková, E.; Lebeda, A.; Katovská, J. Response of Cucumis melo genotypes MR-1 and PI 124112 to Czech isolates of Cucurbit powdery mildew. Acta Hortic. 2002, 588, 181-184. [CrossRef]

17. McCreight, J.D. Genes for resistance to powdery mildew races 1 and 2U.S. in melon PI 313970. HortScience 2003, 38, 591-594. [CrossRef]

18. Romero, D.; Pérez-García, A.; Rivera, M.E.; Cazorla, F.M.; de Vicente, A. Isolation and evaluation of antagonistic bacteria towards the cucurbit powdery mildew fungus Podosphaera fusca. Appl. Microbiol. Biotechnol. 2004, 64, 263-269. [CrossRef]

19. Huggenberger, F.; Collins, M.A.; Skylakakis, G. Decreased sensitivity of Sphaerotheca fuliginea to fenarimol and other ergosterolbiosynthesis inhibitors. Crop Prot. 1984, 3, 137-149. [CrossRef]

20. McGrath, M.T.; Shishkoff, N. Resistance to triadimefon and benomyl: Dynamics and impact on managing cucurbit powdery mildew. Plant Dis. 2001, 85, 147-154. [CrossRef]

21. McGrath, M.T.; Shishkoff, N. First report of the cucurbit powdery mildew fungus (Podosphaera xanthii) resistant to strobilurin fungicides in the United States. Plant Dis. 2003, 87, 1007. [CrossRef]

22. Lebeda, A.; Sedláková, B. Fungicide resistance in populations of cucurbit powdery mildew. J. Plant Pathol. 2008, 90, S2.142.

23. Takikawa, Y.; Nonomura, T.; Miyamoto, S.; Okamoto, N.; Murakami, T.; Matsuda, Y.; Kakutani, K.; Kusakari, S.; Toyoda, H. Digital microscopic analysis of developmental process of conidiogenesis by powdery mildew pathogens isolated from melon leaves. Phytoparasitica 2015, 43, 517-530. [CrossRef]

24. Braun, U. A monograph of the Erysiphales (powdery mildews). Beih. Nova Hedwig. 1987, 89, 1-700.

25. Braun, U.; Cook, R.T.A. Taxonomic Manual of the Erysiphales (Powdery Mildews); CBS-KNAW Fungal Biodiversity Centre: Utrecht, The Netherlands, 2012.

26. Cosme, B.-R.; Josefina, L.-F.; Raúl, A.-M.; María Dolores, M.-R.; José Armando, C.-F.; José Benigno, V.-T.; Fabiola Sary Mell, L.-S.; Raymundo Saúl, G.-E. Characterization of powdery mildew in cucumber plants under greenhouse conditions in the Culiacan Valley, Sinaloa, Mexico. Afr. J. Agric. Res. 2012, 7, 3237-3248. 
27. Hirata, T.; Cunnington, J.H.; Paksiri, U.; Limkaisang, S.; Shishkoff, N.; Grigailiunaite, B.; Sato, Y.; Takamatsu, S. Evolutionary analysis of subsection Magnicellulatae of Podosphaera section Sphaerotheca (Erysiphales) based on the rDNA internal transcribed spacer sequences with special reference to host plants. Can. J. Bot. 2000, 78, 1521-1530.

28. Chen, R.-S.; Chu, C.; Cheng, C.-W.; Chen, W.-Y.; Tsay, J.-G. Differentiation of two powdery mildews of sunflower (Helianthus annuus) by a PCR-mediated method based on ITS sequences. Eur. J. Plant Pathol. 2008, 121, 1-8. [CrossRef]

29. Suzuki, T.; Nishimura, S.; Yagi, K.; Nakamura, R.; Takikawa, Y.; Matsuda, Y.; Kakutani, K.; Nonomura, T. Effects of light quality on conidiophore formation of the melon powdery mildew pathogen Podosphaera xanthii. Phytoparasitica 2018, 46, 31-43. [CrossRef]

30. Hogewoning, S.W.; Trouwborst, G.; Maljaars, H.; Poorter, H.; van Ieperen, W.; Harbinson, J. Blue light dose-responses of leaf photosynthesis, morphology, and chemical composition of Cucumis sativus grown under different combinations of red and blue light. J. Exp. Bot. 2010, 61, 3107-3117. [CrossRef]

31. Schmidt, D.; Wust, G.L.F.; Fontana, D.C.; Pretto, M.M.; dos Santos, J.; Mariotto, A.B.; de Azevedo, G.C.V.; de Cristo, J.A Physiological quality of cucurbits in spectral qualities. EJFA 2020, 32, 92-99. [CrossRef]

32. Solano, C.J.; Hernández, J.A.; Suardíaz, J.; Barba-Espín, G. Impacts of LEDs in the red spectrum on the germination, early seedling growth and antioxidant metabolism of pea (Pisum sativum L.) and melon (Cucumis melo L.). Agriculture 2020, 10, 204. [CrossRef]

33. Suzuki, T.; Nakamura, R.; Takagi, N.; Takikawa, Y.; Kakutani, K.; Matsuda, Y.; Matsui, K.; Nonomura, T. Quantitative analysis of the lifelong production of conidia released from single colonies of Podosphaera xanthii on melon leaves using electrostatic techniques. Austral. Plant Pathol. 2019, 48, 297-307. [CrossRef]

34. Moriura, N.; Matsuda, Y.; Oichi, W.; Nakashima, S.; Hirai, T.; Nonomura, T.; Kakutani, K.; Kusakari, S.; Higashi, K.; Toyoda, H. An apparatus for collecting total conidia of Blumeria graminis $\mathrm{f}$. sp. hordei from leaf colonies using electrostatic attraction. Plant Pathol. 2006, 55, 367-374.

35. Moriura, N.; Matsuda, Y.; Oichi, W.; Nakashima, S.; Hirai, T.; Sameshima, T.; Nonomura, T.; Kakutani, K.; Kusakari, S.; Higashi, K.; et al. Consecutive monitoring of lifelong production of conidia by individual conidiophores of Blumeria graminis $\mathrm{f}$. sp. hordei on barley leaves by digital microscopic techniques with electrostatic micromanipulation. Mycol. Res. 2006, 110, 18-27. [PubMed]

36. Nonomura, T.; Matsuda, Y.; Xu, L.; Kakutani, K.; Takikawa, Y.; Toyoda, H. Collection of highly germinative pseudochain conidia of Oidium neolycopersici from conidiophores by electrostatic attraction. Mycol. Res. 2009, 113, 364-372. [CrossRef]

37. Matsuda, Y.; Ikeda, H.; Moriura, N.; Tanaka, N.; Shimizu, K.; Oichi, W.; Nonomura, T.; Kakutani, K.; Kusakari, S.; Higashi, K.; et al. A new spore precipitator with polarized dielectric insulators for physical control of tomato powdery mildew. Phytopathology 2006, 96, 967-974. [CrossRef]

38. Sameshima, T.; Kashimoto, K.; Kida, K.; Matsuda, Y.; Nonomura, T.; Kakutani, K.; Nakata, K.; Kusakari, S.; Toyoda, H. Cytological events in tomato leaves inoculated with conidia of Blumeria graminis f. sp. hordei and Oidium neolycopersici KTP-01. J. Gen. Plant Pathol. 2004, 70, 7-10. [CrossRef]

39. Oichi, W.; Matsuda, Y.; Nonomura, T.; Toyoda, H.; Xu, L.; Kusakari, S. Formation of conidial pseudochains by tomato powdery mildew. Plant Dis. 2006, 90, 915-919. [CrossRef]

40. Schuerger, A.C.; Brown, C.S. Spectral quality affects disease development of three pathogens on hydroponically grown plants HortScience 1997, 32, 96-100. [CrossRef]

41. Wang, H.; Jiang, Y.P.; Yu, H.J.; Xia, X.J.; Shi, K.; Zhou, Y.H.; Yu, J.Q. Light quality affects incidence of powdery mildew, expression of defense-related genes and associated metabolism in cucumber plants. Eur. J. Plant Pathol. 2010, 127, 125-135. [CrossRef]

42. Shibuya, T.; Itagaki, K.; Tojo, M.; Endo, R.; Kitaya, Y. Fluorescent illumination with high red-to-far-red ratio improves resistance of cucumber seedlings to powdery mildew. HortScience 2011, 46, 429-431. [CrossRef]

43. Suthaparan, A.; Stensvand, A.; Solhaug, K.A.; Torre, S.; Telfer, K.; Ruud, A.; Cadle-Davidson, L.; Mortensen, L.; Gadoury, D.M.; Seem, R.C.; et al. Suppression of cucumber powdery mildew by UV-B is affected by background light quality. Phytopathology 2012, 102, S4.116.

44. Suthaparan, A.; Torre, S.; Mortensen, L.M.; Gislerød, H.R.; Solhaug, K.A.; Stensvand, A.; Gadoury, D.M. Interruption of the night period by UV-B suppresses powdery mildew of rose and cucumber. Acta Hortic. 2012, 956, 617-620. [CrossRef]

45. Suthaparan, A.; Stensvand, A.; Solhaug, K.A.; Torre, S.; Telfer, K.H.; Ruud, A.K.; Mortensen, L.M.; Gadoury, D.M.; Seem, R.C.; Gislerød, H.R. Suppression of cucumber powdery mildew by supplemental UV-B radiation in greenhouses can be augmented or reduced by background radiation quality. Plant Dis. 2014, 98, 1349-1357. [CrossRef]

46. Mieslerová, B.; Lebeda, A. Influence of temperature and light conditions on germination, growth and conidiation of Oidium neolycopersici. J. Phytopathol. 2010, 158, 616-627.

47. Willocquet, L.; Colombet, D.; Rougier, M.; Fargues, J.; Clerjeau, M. Effects of radiation, especially ultraviolet B, on conidial germination and mycelial growth of grape powdery mildew. Eur. J. Plant Pathol. 1996, 102, 441-449. [CrossRef]

48. Kanto, T.; Matsuura, K.; Yamada, M.; Usami, T.; Amemiya, Y. UV-B radiation for control of strawberry powdery mildew. Acta Hortic. 2009, 842, 359-362. [CrossRef]

49. Kanto, T.; Matsuura, K.; Ogawa, T.; Yamada, M.; Ishiwata, M.; Usami, T.; Amemiya, Y. A new UV-B lighting system controls powdery mildew of strawberry. Acta Hortic. 2014, 1049, 655-660. [CrossRef]

50. Suthaparan, A.; Stensvand, A.; Torre, S.; Herrero, M.L.; Pettersen, R.I.; Gadoury, D.M.; Gislerød, H.R. Continuous lighting reduces conidial production and germinability in the rose powdery mildew pathosystem. Plant Dis. 2010, 94, 339-344. [CrossRef] 
51. Suthaparan, A.; Torre, S.; Stensvand, A.; Herrero, M.L.; Pettersen, R.I.; Gadoury, D.M.; Gislerød, H.R. Specific light-emitting diodes can suppress sporulation of Podosphaera pannosa on greenhouse roses. Plant Dis. 2010, 94, 1105-1110. [CrossRef]

52. Suthaparan, A.; Stensvand, A.; Solhaug, K.A.; Torre, S.; Mortensen, L.M.; Gadoury, D.M.; Seem, R.C.; Gislerød, H.R. Suppression of powdery mildew (Podosphaera pannosa) in greenhouse roses by brief exposure to supplemental UV-B radiation. Plant Dis. 2012, 96, 1653-1660. [CrossRef]

53. Oichi, W.; Matsuda, Y.; Sameshima, T.; Nonomura, T.; Kakutani, K.; Nishimura, H.; Kusakari, S.; Toyoda, H. Consecutive monitoring for conidiogenesis by Oidium neolycopersici on tomato leaves with a high-fidelity digital microscope. J. Gen. Plant Pathol. 2004, 70, 329-332. [CrossRef]

54. Whitelam, G.C.; Halliday, K.J. Light and Plant Development; Blackwell Publishing Ltd.: Oxford, UK, 2007 ; pp. 1-325.

55. Brown, C.S.; Schuerger, A.C.; Sager, J.C. Growth and photomorphogenesis of pepper plants under red light-emitting diodes with supplemental blue or far-red lighting. J. Amer. Soc. Hort. Sci. 1995, 120, 808-813. [CrossRef]

56. Bukhow, N.G.; Drozdova, I.S.; Bondar, V.V. Light response curves of photosynthesis in leaves of sun-type and shade-type plants grown blue or red light. J. Photochem. Photobiol. B Biol. 1995, 30, 39-41. [CrossRef]

57. Yorio, N.C.; Goins, G.D.; Kagie, H.R.; Wheeler, R.M.; Sager, J.C. Improving spinach, radish, and lettuce growth under red light-emitting diodes (LEDs) with blue light supplementation. HortScience 2001, 36, 380-383. [CrossRef]

58. Taiz, L.; Zeiger, E.; Møller, I.M.; Murphy, A. Fisiologia e Desenvolvimento Vegetal, 6th ed.; Artmed: Porto Alegre, Brazil, 2017. 